\title{
Scientialiberatio Pooullorum \\ Assessment of Geotechnical Parameters of Lateritic Soil of Jos and Environs, for Civil Engineering Constructions North Central part of Nigeria.
}

${ }^{1}$ Vincent, E., ${ }^{\text {Dominic, P., }}{ }^{2}$ and Kure, M.M. ${ }^{3}$

1Department of Geology University of Jos P.M.B 2084 Jos, Plateau State Nigeria.

2School of General and Applied Sciences Shehu Idris College of Health Sciences and Technology, P.M.B 1050 Makarfi, Kaduna State Nigeria. 3Department of Building Technology Nuhu Bamali Polytechnic P.M.B 1061 Zaria, Kaduna, State Nigeria.

*Corresponding E-mail: emmvins@gmail.com

\begin{abstract}
Due to failures of Civil Engineering structures in Jos and its Environs, Geotechnical parameters of Lateritic soils were carried out in order to determine its engineering properties for civil engineering construction. The methods involved are; reconnaissance survey, site works, laboratory tests based on British Standard (BS) methods and interpretation of the results. The laboratory test of the soils revealed that the Atterberg limit; Liquid limit (LL) ranged from 33.0\% to 45.0\%, Plastic limit (PL) from $16.23 \%$ to $26.37 \%$, and Plasticity index (PI) from $8.63 \%$ to $22.67 \%$. The percentage passing from the Sieve analysis ranges from $31.62 \%$ to $67.66 \%$. The cohesive strength (c) and angle of internal friction $(\varnothing)$ from direct shear test ranged from $13 \mathrm{KN} / \mathrm{m}^{2}$ to $24 \mathrm{KN} / \mathrm{m}^{2}$ and $9^{\circ}$ to $26^{\circ}$. The values of the Total settlement $(\mathrm{Pc})$ from the Consolidation test ranged from $0.0005 \mathrm{~m}$ to $0.0019 \mathrm{~m}$, Soil pH from 5.2 to 7.8 , Specific gravity (SG) from 2.57 to 2.73 and Natural Moisture Content (NMC) from $8.18 \%$ to $46.36 \%$. From the compaction test; the Optimum Moisture Content (OMC) ranged from $15.22 \%$ to $20.60 \%$ and Maximum Dry Density (MDD) from $1.62 \mathrm{~g} / \mathrm{cm}^{3}$ to $1.84 \mathrm{~g} / \mathrm{cm}^{3}$. The California Bearing Ratio (CBR) test for the soaked soils ranged from $21.0 \%$ to $93.0 \%$ and Unsoaked values from $50.75 \%$ to $96.61 \%$. The findings reveal that; the geology of the area can be largely classified into granites (Biotite-microgranite, N'gell biotite-granite, Jos-biotite-granite and Aplo-pegmatitic granite-gneiss) and laterites. The geotechnical parameters of the soil are characteristically fair to poor, the strength and deformation of the soil reveals that it can mostly be used as a sub-base materials. The soil is classified as silty-clay, and the area need to be stabilized with cement, sand and gravel before carry civil engineering constructions. The results obtained will serve as base-line information for civil engineering construction in the study area in other to avoid structural damage.
\end{abstract}

Keywords: Civil Engineering Constructions, Geotechnical parameters, Lateritic soil, North Central Nigeria. 


\section{Introduction}

The construction of civil engineering structures like building, bridge, highway, tunnel, tower, dams, roads, airfield, retaining wall and railway are founded below or on the surface of the earth (Roy and Bhalla, 2017). To ensure their stability, suitable foundation soil is required. To check the suitability of soil to be used as foundation or as construction materials, its engineering properties are required to be assessed adequately (Laskar and Pal, 2012). The need to understand soil behaviour in solving engineering problems such as swelling soil will help to prevent significant damage to civil engineering structures (Abubakar, 2016; Oke and Amadi, 2008). The assessment of geotechnical parameters of subsoil is necessary for generating relevant input data for design and construction of foundations for any proposed structures (Oke et al., 2008; Nwankwoala and Warmate, 2014).

The use of lateritic soils has wide applications in civil engineering constructions. Prominent among their uses is in roads, airfield, and highway pavement where they are utilized as fill materials and also for making compressed earth block (CEB) for buildings. Laterites are known to be rich in iron oxides and alumina sesquoxides with varying contents of silica depending on the degree of weathering and decomposition experienced (Lar et al., 2011). According to Amadi et al., (2012) the mineralogical composition of the lateritic soil has an influence on the geotechnical parameters such as Specific gravity, Shear strength, Swelling potential, Atterberg limits, Bearing capacity and Petrographic properties. The characteristics and durability of any construction materials like lateritic soil is a function of its efficiency in response to the load applied (Oke et al., 2009b; Nwankwoala and Amadi, 2013). Many construction works have been costly, largely because the sites has been badly selected, and there have been an examples of civil engineering structures such as roads, bridges, dams, retaining walls and buildings which failed because the soils were too weak to support them. Failure of civil engineering structures like Roads and Buildings in Jos North and Environs Area of Plateau State, North Central part of Nigeria is due to cracks, potholes, deformation and peeling. This has led to the geotechnical assessment of the soil parameters to improve the construction of any civil engineering structures. Hence this study will ensure the right lateritic soils with the right criteria for used, thereby ensuring their durability. Adequate knowledge and recommendations concerning geologic interpretation is essential in the exploration process for civil engineering constructions (Williams, 2016). However, due to nonuniqueness of geophysical results, geological data are essential for reliable geophysical interpretations for civil engineering works (Anderson and Croxton, 2008; Salami, 2017). According to Omotoso (2010), geotechnical investigation of lateritic soil is important for the construction of civil engineering structures like road, highways and airfields. Failures of civil engineering structures in Nigeria are generally due to poor geotechnical parameters of the underlying soils as well as the type and content of secondary minerals Agbede (1992). Information about the surface and sub-surface features is essential for the design of structures and for planning construction techniques, and this involve detailed explorations to determine the engineering properties of the soils for different strata (Arora, 2008). According to Oke et al., (2009a) and Nwankwoala et al., (2014), failure of engineering structures like bad road can results to road accident due to wrong application of constructional materials, especially the use of laterite as a base and sub-base material by construction companies. Nigeria is one of the countries with the highest records of roads, buildings, dams and bridge failures with incessant loss of lives and properties due to poor geotechnical parameters of the underlying soils. Lack of understanding of the soil parameters can lead to the construction errors. The suitability of soil for a particular use should be determined based on its engineering characteristics and not on visual inspection or apparent similarity to other soils. According to 
Oghenero et al., (2014), Youdeowei and Nwankwoala (2013), Ngah and Nwankwoala (2013), Caleb et al., (2013) and Amadi (2013), they are of the opinion that proper design and construction, adequate geologic and geotechnical investigations will help to prevents the failure of civil engineering structures and other post construction problems. Utilization of locally available soil for civil engineering construction will optimize the cost and to reduce the environmental impact associate with constructions works (Tharaka and Mampearachichi, 2012). Civil engineering structures like African megaliths in Tazunu, located in the North-western part of the Central African Republic, was investigated by Billong et al., (2009) and concludes that it is of lateritic origin, in addition to rock minerals. The need to reduce environmental and social impact from the construction industry has led to a renewed interest in earth construction works (Hamard et al., 2016). In this case the engineering geologist or construction engineers are expected to give predictions of the behaviour of the soils in projects involving preliminary designs. In case of the use of weak soil in civil engineering construction there is need to carryout soil stabilization. This idea has been known for centuries, and the use of straw to strengthen unburnt clay bricks and fascine mattresses from ancient times has been used to strengthen soft soil deposits prior to civil engineering construction. Ziggurats, built in Iraq consist of dried earth blocks, reinforced across the width of the structure with tarred ropes, Smith and Smith (1998). Weak or peat soils are stabilized due to high initial water content in order to reduce their moisture content Behzad and Huat (2008). Geotechnical parameters of soils influence the stability of civil engineering structures (Roy and Bhalla, 2017). The objectives of this research are to; assess the geological, geotechnical, strength and deformation, provide soil classification and stabilization for the study area.

\section{Location of the Study Area}

The study area is located in Jos North Local Government Area of Plateau State North-Central part of Nigeria and its Environs. It falls within latitude $9^{\circ} 53^{\prime} 30^{\prime \prime} \mathrm{N}$ to $9^{\circ} 56^{\prime}$ $00^{\prime \prime} \mathrm{N}$ and longitude $8^{\circ} 51^{\prime} 00^{\prime \prime} \mathrm{E}$ to $8^{\circ} 54^{\prime} 00^{\prime \prime} \mathrm{E}$ (Figure 1), and is accessible due to the presence of major road, footpath and cattle tracks. The climatic condition of the study area is characterized by alternating wet and dry season coded as 'AW' by Koppen's classification with an elevation of about 1287 meters above sea level. The area experiences a mean annual rainfall of $1260 \mathrm{~mm}$ (1050-1403mm), peaking between July and August and the mean temperature ranges from $19.4^{\circ} \mathrm{C}-24.5^{\circ} \mathrm{C}$ (Okpara et al., 2015). The vegetation of the study area lies within the Guinea savannah zone classified as woodland savannah dominated by grasses (Abiem, 2016). The formation of lateritic soil in the study area depends on the geology and the climatic condition of the area. 


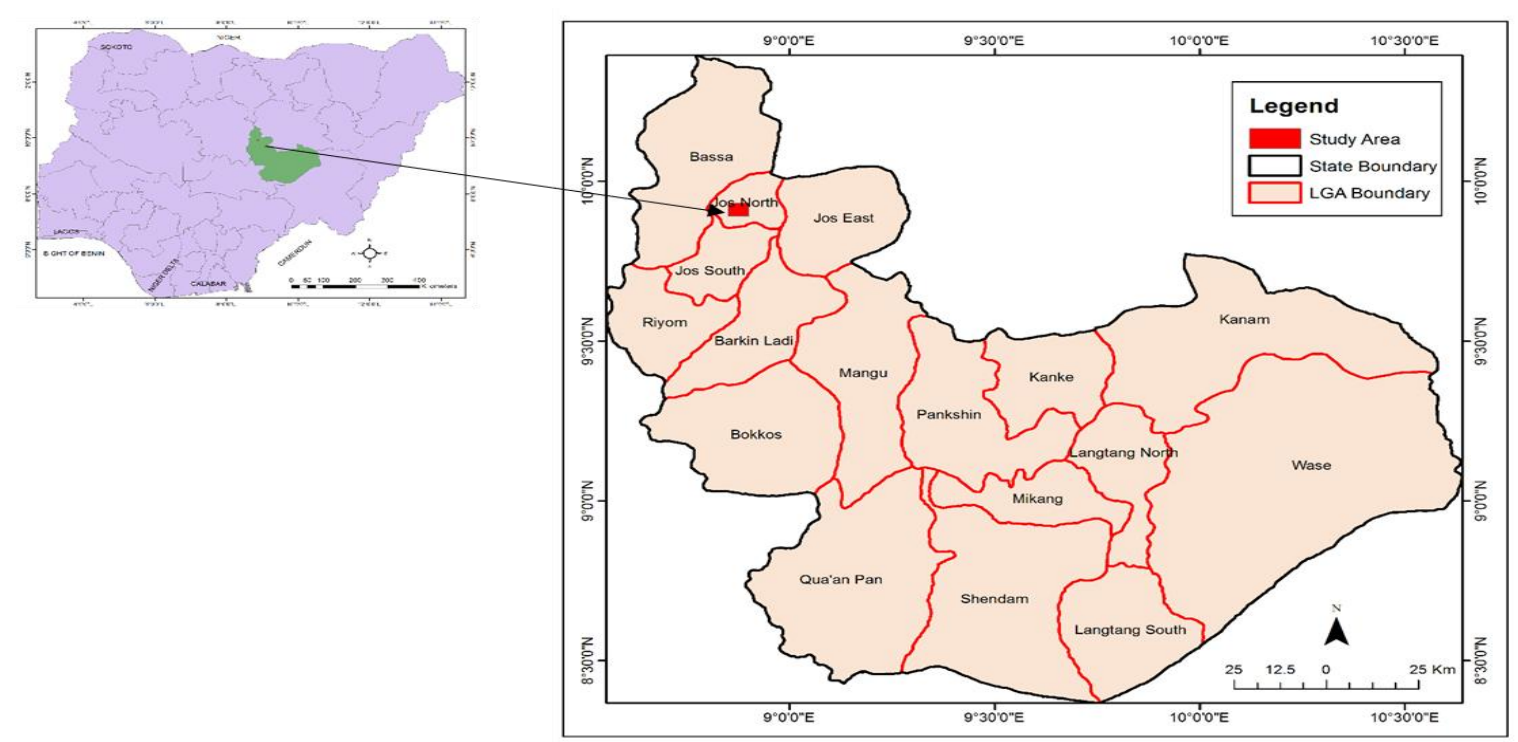

Figure 1: Location Map of the study area.

\section{Drainage and Topography}

The drainage pattern of the study area is parallel and this comprises of numerous rivers which are parallel to each other and follow the regional slope (Figure 2). This pattern is due to dipping nature of the rock beds. It cut across the Basement areas around Delimi to British American Junction, Gada Biu Motor Park, Mado Tourism and Sabon Gari, and also between Polo Field and Jubilee Hotel, Zaria Bye-pass. The drainage is tectonically controlled as it is seen by its parallelism with the dominant N-S structures of the host rocks.
The topography of the study area slopes generally towards different directions in different locations, and is divided into three broad units; hills and mountains, dissected, and undulating terrain. The nature of the relief is closely related to the underlying rock types that formed a resistant core through a long erosional history and still form the hill masses of the present landscape rising to over $1000 \mathrm{~m}$ above mean sea level (Figure 3). The morphology of these hills is largely controlled by the joint pattern and the underlying rock is obscured by unconsolidated material with iron pans. 


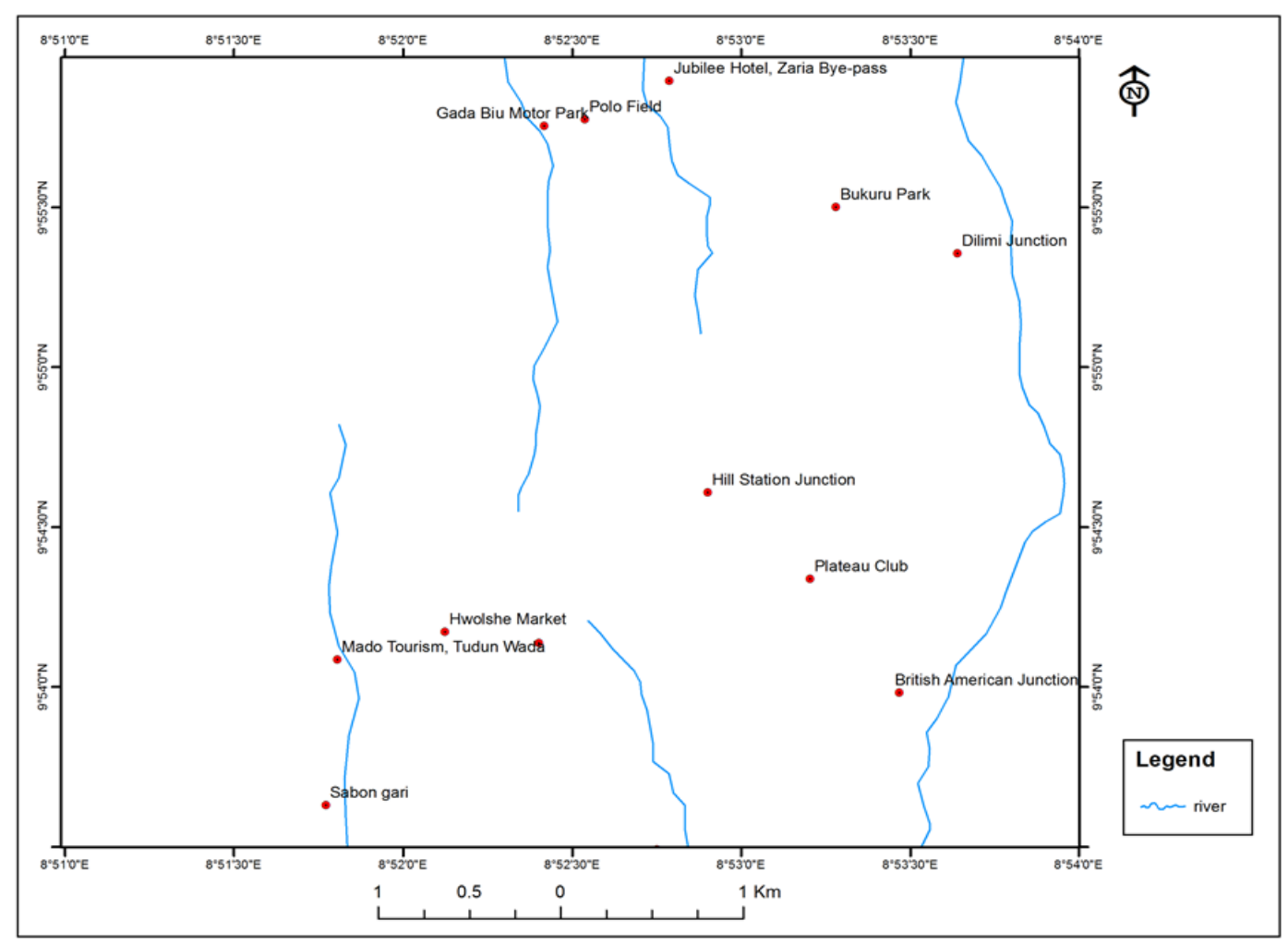

Figure 2: Drainage Map of the study area.

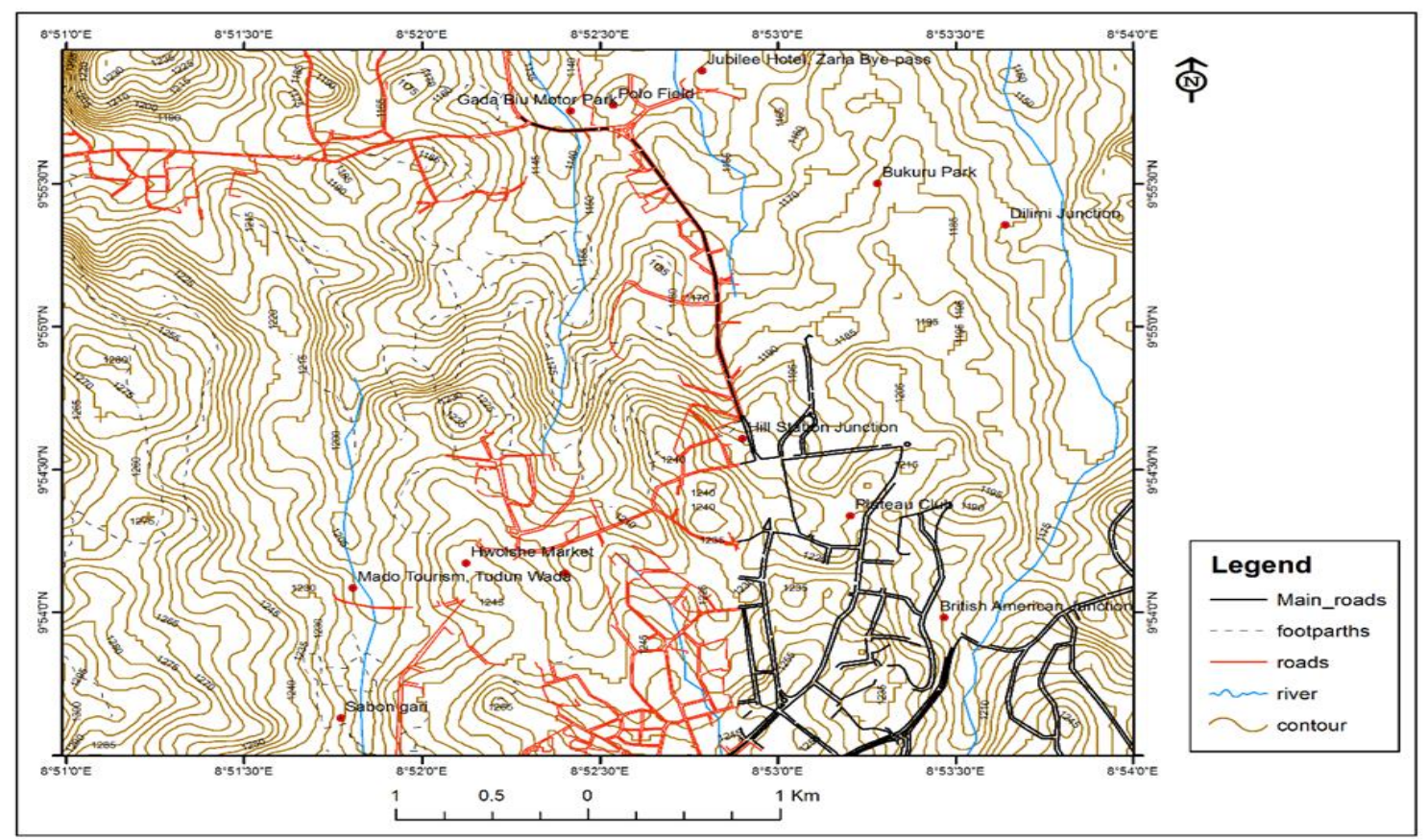

Figure 3: Topographic Map of the study area. 


\section{Materials and Methods}

The methods adopted for this study includes; reconnaissance survey, site works (disturbed and undisturbed soil sample collection), laboratory tests, and interpretation of the results. The reconnaissance survey involved surface geological mapping in order to ascertain the local geology of the area. During this survey observation and description of soils and rocks in the area were undertaken. A total of twenty (20) soil samples from ten trial pits were collected, ten (10) for the undisturbed samples while the remaining ten (10) are for disturbed. The disturbed soil samples were collected via the use of digging tools while the undisturbed soil samples were collected via the use of core cutter both at the depth of $1.0 \mathrm{~m}$. The rock samples were only studied in-situ. The collected soil samples were subjected to two classes of laboratory tests which include; Soil classification tests (Moisture content, Atterberg limits, Specific gravity, Soil $\mathrm{pH}$, and Particle size distribution also known as Sieve analysis) and Soil strength tests (Compaction, Consolidation, Direct shear and California Bearing Ratio). The Laboratory tests were carried out in accordance with BS 1377 (1990) and BSI 5930 (1990).

(1). Sieve analysis: Were carried out in order to determine the grain size distribution of the soil particles. Apparao and Rao (1995) explained that the grain size analysis is widely used in classification of soils.

Apparatus used: This involves the use of British Standard sieve, a heavy duty balance, a wire brush, rubber hammer, electric oven, large metal tray, sample containers of known weight, trowel and water.

Test procedure: Representative sample of approximately $500 \mathrm{~g}$ was used for the test after washing and oven-dried. The sample was washed using the BS 200 sieve and the fraction retained on the sieve was air dried and used for the sieve analysis. The sieving was done by mechanical method using an automatic shakers and a set of sieves. Both wet and dry Sieve was carried out quantitatively to know the proportion by weight of the various sizes of particles present in the soil. Soils have wide range of particles sizes with different particles ranging from; Gravel $60.0-2.0(\mathrm{~mm})$, Sand 2.0$0.06(\mathrm{~mm})$, Silt $0.06-0.002(\mathrm{~mm})$ and Clay $0.002(\mathrm{~mm})$ equivalent particle diameter. For the coarse grain soil analysis, the gravel fraction retained on the No.7 B.S. Sieve is passed into Sieves; $38.1,19.05 \mathrm{~mm}, 9.35 \mathrm{~mm}$ and $4.76 \mathrm{~mm}$ B.S Sieve and the portion retained on each Sieve accompanied by a jarring action. For the fine grain analysis the sample which passes No. 7 B.S. Sieve are weighed and properly washed. The suspension was carefully removed and passed through No. 200 B.S. Sieve. The washed and retained materials on the No. 200 B.S. Sieve (during washing) were dried in the oven. After drying the material is Sieved (in dry state) on the Nos $10,14,18,25$, $36,52,72,100,150$ and 200 B.S. Sieve. For the coarse analysis the Percentage (\%) by weight of material will retained on the $38.1 \mathrm{~mm}$, $19.05 \mathrm{~mm}$ and $4.76 \mathrm{~mm}$ B.S. Sieve. From these values the cumulative percentage by weight of the total sample passing the Sieve were calculated. In the analysis of fine materials, the percentage $(\%)$ of coarse, medium and fine sand in the sample will be calculated. The result of the coarse and fine analysis was plotted on semi-logarithmic graph. The percentages of the various fractions are expressed to the nearest $1 \%$ and were plotted against the corresponding grain size. Alternatively, the results may be given in a tabular form, as the percentage of gravel, sand and clay in the original pre-treated soil sample.

(2). Compaction test: Is the process by which the solid soil particles are packed more closely together by mechanical means, thus increasing the dry density Prakash and Jain (2002).

Apparatus used: This involves the use of Compaction mould, capacity $1000 \mathrm{ml}$, Rammer, Mass $2.6 \mathrm{~kg}$, Detachable base plate, Collar $60 \mathrm{~mm}$ high, IS sieve $4.75 \mathrm{~mm}$, Oven, Desiccator, Weighing balance accuracy $1 \mathrm{~g}$, Large mixing pan, Straight edge, Spatula, Graduated jar, Mixing tools, spoons and trowels. 
Test procedure: The mould and the base plate was first cleaned and greased lightly. The mould was weighed to the nearest 1 gram. About $16-18 \mathrm{~kg}$ of soil specimen was taken and water was added to it. The soil was kept in an air-tight container for about 18 to 20 hours for maturing. The soil was then mixed thoroughly and was divided into 5 parts. The collar was attached to the mould and the mould was placed on a solid base and about $2.5 \mathrm{~kg}$ of the processed soil was placed in the mould in 3 equal layers. About one-third of the quantity was first taken, and was compacted by giving 25 blows of the rammer. The blows were uniformly distributed over the surface of each layer. The top surface of the first layer was scratched with spatula before placing the second layer. The second layer was also compacted for 25 blows of rammer. Likewise, the third layer was placed and compacted. The amount of the soil used was sufficient to fill the mould leaving about $5 \mathrm{~mm}$ above the top of the mould to be struck off when the collar is removed. The collar was removed and trims off the excess soil projecting above the mould using a straight edge. The base plate and the mould were cleaned from the outside and were weighed to the nearest gram again. After that the soil was removed from the mould. The soil samples were taken for the water content determination from the top, middle and bottom portions. The water content was determined and about $3 \%$ of the water was added to a fresh portion of the processed soil and the steps was repeated.

(3). Atterberg Limits (Liquid Limit, Plastic Limit, linear shrinkage and Plasticity Index): This test determines the clay content in terms of liquid limit, plastic limit, plasticity index and shrinkage potential in order to estimate plasticity, strength and settlement characteristics of the soil sample (Atterberg, 1911).

Apparatus used: This involves the use of Liquid limit device and grooving tools, distilled water, drying oven, weighing balance, desiccators, evaporating dish, watch glasses, drying cans and spatula.
Test procedure: (a). The Liquid Limit: The Liquid Limit of a soil is the water content, normally in percentage, at which the two sides of a groove cut in the soil sample contained in the cup of a Casagrande device would touch over a length of $12 \mathrm{~mm}$ after 25 impacts or above (Casagrande, 1952). It can also be describe as the minimum moisture content at which the soil will flow under its own weight. As the moisture is removed from a fine-grained soil it passes through a series of states that is liquid, plastic, semi-solid and solid. The moisture content of soil at the points where it passes from one stage to the next is known as consistency. The limit was determined on the portion of the soil finer than a No. 40 sieve or 36 sieves. About $100 \mathrm{gms}$ of moist soil was mixed thoroughly with distilled water to form a uniform paste. The portion of the paste was placed in the cup of the liquid limit device; smoothen the surface off a maximum depth of $1 / 2$ inch $(12.5 \mathrm{~mm})$ and draw the grooving tool through the sample along the symmetric axis of the cup, holding the tool perpendicular to the cup at the point of contact. The crank was turned at a rate of about two revolutions per second in other to count the blows necessary to close the groove in the soil on a distance of $1 / 2$ inch $(12.5 \mathrm{~mm})$. The groove was closed by the flow of the soil and not by slippage between the soil and the cup. About 10gms of soil was taken at approximately near the closed groove for a water content determination. By altering the water content of the soil, about four water content determinations in the range of ten to four blows was carried out. A graph of water content (\%) against the number of blows was plotted. From the graph plotted, the liquid limit is the moisture content corresponding to twenty-five (25) number of blows.

(b). The Plastic Limit: The Plastic Limit is the minimum water content, in percentage, of a soil at which threads of $3 \mathrm{~mm}$ thickness can be rolled out without crumbling or breaking. About 100 grams of moist soil was rolled out into the thin threads on the glass plate without stretched fingers. The threads are folded and rolled out again until at a diameter of $3 \mathrm{~mm}$ start to crumble. For checking the diameter a short metal rod was 
kept at hand. The average moisture content of the test gives the plastic limit.

(c). The linear shrinkage: The linear shrinkage is the maximum moisture content at which further loss of moisture does not causes a decrease in the volume of the soil. The linear Shrinkage limit was determined by the use of Mould and Oven. The mould was thoroughly cleaned and a thin film of grease is applied to its inner walls in order to prevent the soil from adhering to the mould. A soil sample weighing about $150 \mathrm{~g}$ was taken from the material passing sieve No. 36 (425 micrometre) was placed on flat glass plate and thoroughly mixed with distilled water until the soil becomes a smooth homogeneous paste, with moisture content approximately the liquid limit of the soil. The mixed was then placed into the mould; the mould was then jarred in other to remove any air pockets in the mixture. The soil was levelled off along the top of the mould with the palette knife and all soil adhering to the walls of the mould shall be removed by wiping with a damp cloth. The soil-water paste was placed in the mould such that it is slightly above the sides of the mould. Then the mould with the soil paste is dried in the oven for 24hours at a temperature of $105^{\circ} \mathrm{C}$ to $110^{\circ} \mathrm{C}$. The soil and the mould were removed from the oven, allowed to cool off and the mean length of the soil bar was measured. If the bar becomes curved during drying, it shall be carefully removed from the mould and the top and bottom length measured with a thread. The mean of these two lengths shall be taken as the lengths of the oven-dried specimen.

(4). Soil pH (soil and water) test: Were carried out to determine the acidity, neutrality and alkalinity of the soil (Odesina, 2012).

Apparatus used: This involved the use of beaker, pH Meter (Hanna), a $40 \mathrm{~g}$ of dried and sieved soil with $40 \mathrm{~mL}$ of distilled water and a spoon to transfer the soil.

Test procedure: The soil and the distilled water were thoroughly mixed with a spoon by stirring it. The stirred soil/water mixture was carried out for 30 seconds and then was waited for 3 minutes for a total of five stirring/waiting cycles before dipping the $\mathrm{pH}$ meter into the mixture for $\mathrm{pH}$ recording.

(5). California Bearing Ratio (CBR) Test: Were carried out in other to determine the mechanical strength and the bearing capacity of the soil. It is a semi empirical test that is often employed in the estimation of the bearing capacity of sub-grade, sub-base and base materials (Simon et al., 1973; Gidigasu, 1976).

Apparatus used: This involves the use of Mould, Steel Cutting collar, Spacer Disc, Surcharge weight, Dial gauges, IS Sieves, Penetration Plunger and Loading Machine.

Test procedure: For the soaked method of CBR test; - Compaction test were conducted on the soil samples to determine their optimum moisture content (OMC) and maximum dry density (MDD). The OMC and MDD of each sample were used to prepare a specimen for CBR test after 24hrs of soaking. After which, the CBR specimen was weighed and placed under the CBR machine and seating load of approximately $4.5 \mathrm{~kg}$ was applied. Load was recorded at penetration of 2.5 and $5.0 \mathrm{~mm}$. The average CBR for both ends of the moulded specimen was calculated. For the un-soaked method of CBR test; - A portion of the air-dried sample was mixed with $5 \%$ of its weight of water. This was put in C.B.R mould in 5 layers with each layer compacted with 55 blows using a $4.5 \mathrm{~kg}$ rammer. The compacted soil and the mould was weighed and placed under an automated CBR machine with proving ring factor of $0.0215 \mathrm{KN} / \mathrm{m}^{3}$, and the Load was recorded at penetration interval of $0.25 \mathrm{~mm}$.

(7). Consolidation test (Oedometer): Were carried out to determine the settlement parameters of the soil with respect to Coefficient of Consolidation ( $\mathrm{Cv}$ ), Coefficient of Compressibility (Mv), Total settlement (Pc) and Coefficient of permeability $(\mathrm{K})$ to predict the rate and amount of settlement of a structure founded on a soil primarily due to volume change of the soil (Prakash and Jain, 2002). 
Apparatus used: This involves the use of Oedometer Machine, Slotted (standard) weights, Spatula, Distilled water, Electric Oven, Moisture content cans, Aspirator, weighing balance readable to $0.01 \mathrm{~g}$ and timer (stop watch or table clock).

Test procedure: The test procedure involves the collection of the soil specimen which is undisturbed via the use of core cutter. An undisturbed soil sample was obtained and all the apparatus used was inspected to ensure that they are in good working condition. The specimen was prepared by pressing the consolidation ring against the soil until the ring fully accommodates the soil in it. The excess soil was trimmed on both top and bottom of the ring to obtain a specimen equal the rate dimension of the consolidation ring that is $50 \mathrm{~mm}$ in diameter and $19 \mathrm{~mm}$ in height. The specimen was placed in the ring on the porous stone in the consolidation cell. The guide was placed to hold the specimen firmly in position and the nuts was screwed. The porous stone was placed on the specimen and the loading frame was adjusted to have contact with the soil. The dial gauge was adjusted to zero and distilled water was added to the consolidation cell and was allowed to stay for few minutes before loading. The dial gauge was re-adjusted to zero and the timer to 00: 00: 00. The system was loaded via the loading yoke with $1.00 \mathrm{~kg}$ load and was simultaneously observed by dial gauge readings. The timer was started and was notice until the time elapsed. The dial gauge readings was taken to the corresponding time from the start of the loading; 0.00, 0.25, 1.00, $2.25,4.00,6.25,9.00,12.25,25.00,60.00$, $\delta 120.00,240.00,360.00$ and 1440.00 . If two successive dial readings have the same values at two successive times, the prevailing load on the system should be doubled at any time, as the case may be. The loads were removed after taking the complete dial gauge readings. The load was taken after taking the complete dial gauge readings. The moisture content of the specimen was determined after the test and also the specific gravity of the soil specimen. The laboratory date on the standard form (Data sheet) was entered. The change in thickness $(\delta \mathrm{h})$, thickness of the specimen (h) and the mean thickness of the specimen was computed. The graph of the dial gauge readings on the $\mathrm{Y}$ axis against the square root of time on the $\mathrm{X}$ axis was plotted. The Primary tangent was drawn and also the secondary tangent of 1.15 was also drawn from the primary tangent and the value of t $_{90}$ was determined from the graph.

(8). Natural Moisture Content (NMC) test: Were carried out to determine the existing moisture contained in a given soil sample. It is expressed as a percentage, by comparing with the weight of water to the weight of dry soil (Sidi et al., 2015).

Apparatus used: This involves the use of electric oven, moisture content cans, scoop, weighing balance, desiccator and soil sample.

Test procedure: The test was carried out with an undisturbed soil sample collected from the field. Three moisture cans was obtained and their identification numbers was known and was weighed using the weighing balance empty with their lids in place. The soil sample was mixed thoroughly and about $45 \mathrm{~g}$ of the soil was introduced into each of the cans. The can containing the wet soil was weighed and was put into the electric oven at the regulated temperature of between $105^{\circ} \mathrm{C}-115^{\circ} \mathrm{C}$ with the lids opened. The can was remained in the oven at the regulated temperature range for 24 hours to ensure total dryness. After dryness the container was removed from the oven and the lids was replaced. The can was allowed to cool down in the desiccator for few minutes and the can containing the dried soil was weighed. All the data obtained was recorded to compute the moisture content. The average of the calculated moisture content of the cans give the moisture content of the soil tested.

(9). Specific gravity (SG) test: Were carried out to determine the ratio of the mass of soil solids to the mass of an equal volume of water for qualitative behaviour of soil (Raj, 2012).

Apparatus used: This involves the use of Sample tray, 50ml density bottle, Scoop, weighing balance, funnel, soil sample, distilled water and Aspirator (washed bottle). 
Test procedure: The soil sample was first obtained and was sun dry. The apparatus was first inspected to make sure they are all in good working condition. The empty $50 \mathrm{ml}$ density bottle was weighed. About $50 \mathrm{~g}$ of the dried soil sample was put into the density bottle; the cap was first replaced and was weighed with the dry sample inside the bottle. The Aspirator was used to add the distilled water into the density bottle half way and the content was shaked. The content was added with distilled water to the brim of the density bottle and was replaced with the cap. The water content outside the surface of the density bottle was wiped with a clean cloth. The density bottle, the soil and the distilled water was also weighed. The contents of the density bottle were emptied and were washed again. The density bottle was filled with distilled water and the excess water on the outside surface of the density bottle was wiped and the density bottle plus the mixture (distilled water plus the soil) was also weighed only. The data obtained was recorded in other to compute the specific gravity of the soil. The average value of the calculated specific gravity test was obtained in other to give the final Specific gravity (GS) of the soil tested.

\section{Results}

\section{(a) Geological Analysis}

The geology of the study area can be largely classified into granites (Biotitemicrogranite, N'gell biotite-granite, Josbiotite-granite and Aplo-pegmatitic Granite Gneiss) with lateritic deposit as residual materials derived from the weathering of the rocks (Figure 4). The Jos-Biotite-Granites are the predominate rocks in the area. It is wide spread and occurred as cross cutting sheets with irregular shape. Texturally the rocks is mostly medium to coarse grained and have been affected by weathering along the joint planes thus breaking the rocks into large boulders. According to Akanbi et al., (2012), the Jos-biotite-granite is associated with Cassiterite and these have suffered a higher degree of late albitization. The Cassiterite is also associated with other minerals such as Columbite, Monazite and accessories like Zircon and Topaz. The Aplo-pegmatiticgranite-gneiss occupies a little portion of the geologic map towards the extreme ends and cuts across the Jos-biotite granites. Daku et al., (2019) describe its mode of occurrence as irregular shape. The N'gell-biotite-granite is granular in shape and is usually pink in colour, often associated with Cassiterite and Columbite mineralisation. The Biotite microgranite represents the upper, flat-lying roof sections of the ring intrusions and some of these are remarkably shallow in comparison with their lateral dimensions. Others are stock and bosses with steeply dipping contacts, which probably continued to a considerable depth (Alkali and Yusuf, 2010). The prominent hilly features in the study area are Inselbergs, and whalebacks which belong to the category of residual hills commonly associated with massive granites bodies. Structures (which are generally considered as evidence of deformation left as imprints on rocks) in the area includes; joints, veins, dykes, foliations and faults, trend mainly in the NE$\mathrm{SW}$ and NW-SE direction (Olasehinde et al., 2012). As a result of weathering activity, the rocks of the study area have undergone immense laterization resulting in the formation of laterites in areas that were formerly covered by rocks with only the ironstone capping been seen on the surface (Lar et al., 2011). 


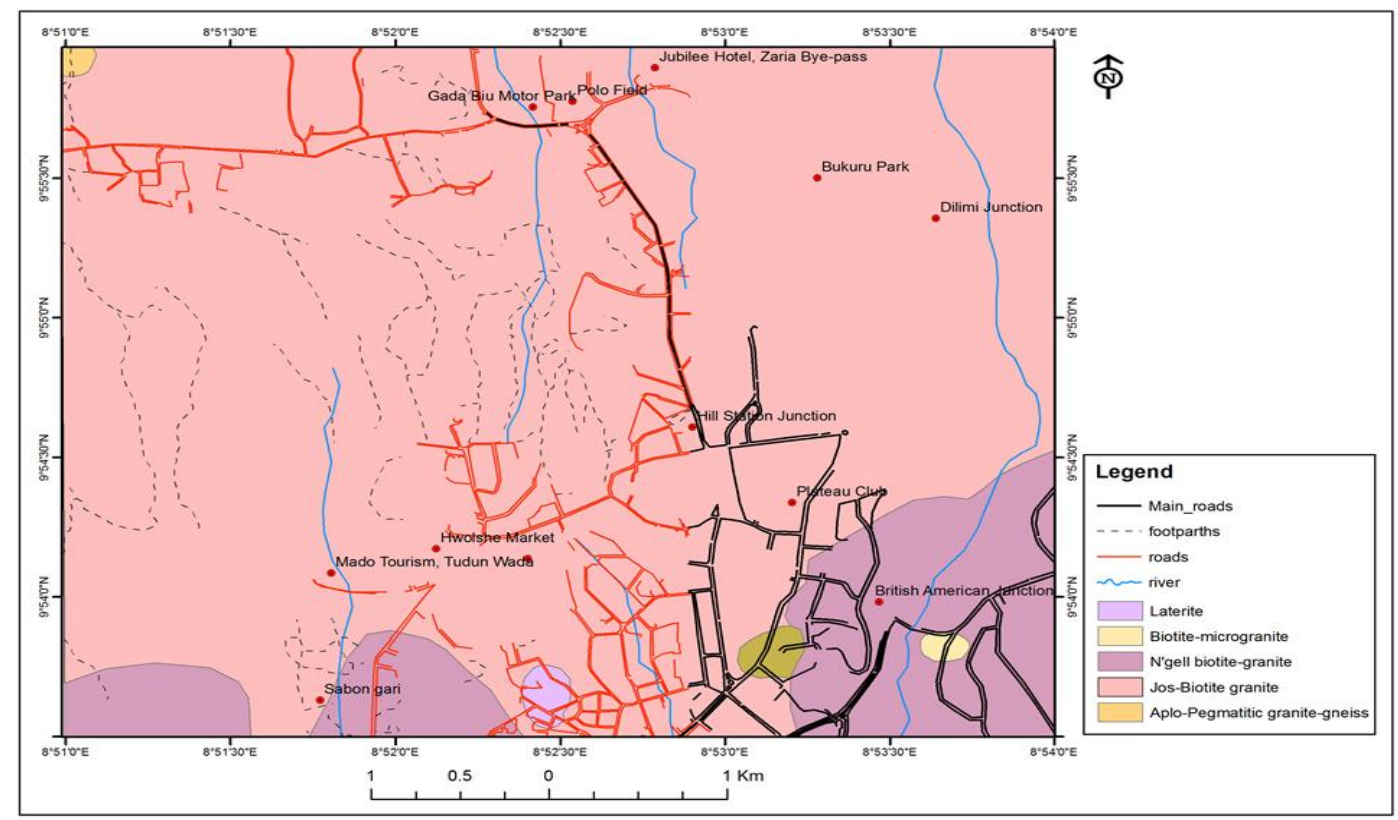

Figure 4: Geological Map of the study area.

Table 1: Summary of the Laboratory Results

\begin{tabular}{|c|c|c|c|c|c|c|c|c|c|}
\hline \multirow{2}{*}{$\begin{array}{c}\begin{array}{c}\text { Trial } \\
\text { pit No }\end{array} \\
-\end{array}$} & \multirow{2}{*}{$\begin{array}{c}\begin{array}{c}\text { Sieve } \\
\text { Analysis } \\
\text { Test }\end{array} \\
(\% \\
\text { passing })\end{array}$} & \multicolumn{2}{|c|}{ Compaction test } & \multicolumn{3}{|c|}{ Atterberg Limit test } & \multirow{2}{*}{$\begin{array}{c}\begin{array}{c}\text { Soil } \\
\text { pH } \\
\text { test }\end{array} \\
-\end{array}$} & \multicolumn{2}{|c|}{$\begin{array}{c}\text { CBR } \\
\text { Value of the soil tested } \\
(\%)\end{array}$} \\
\hline & & $\begin{array}{l}\text { MDD } \\
\left(\mathrm{g} / \mathrm{cm}^{3}\right)\end{array}$ & $\begin{array}{l}\text { OMC } \\
(\%)\end{array}$ & $\begin{array}{l}\text { LL } \\
(\%)\end{array}$ & $\begin{array}{l}\mathrm{PL} \\
(\%)\end{array}$ & $\begin{array}{c}\text { PI } \\
(\%)\end{array}$ & & SOAKED & $\begin{array}{c}\text { UN- } \\
\text { SOAKED }\end{array}$ \\
\hline 1 & 40.76 & 1.84 & 15.22 & 34.00 & 19.14 & 14.86 & 6.5 & 31.00 & 79.47 \\
\hline 2 & 38.42 & 1.71 & 16.35 & 43.00 & 22.15 & 20.85 & 6.9 & 49.50 & 74.50 \\
\hline 3 & 50.54 & 1.64 & 17.62 & 39.00 & 25.66 & 13.34 & 6.6 & 26.30 & 75.10 \\
\hline 4 & 62.68 & 1.82 & 17.05 & 38.00 & 18.33 & 19.67 & 7.8 & 74.70 & 68.31 \\
\hline 5 & 31.62 & 1.62 & 18.19 & 42.00 & 24.05 & 17.95 & 7.4 & 82.70 & 71.85 \\
\hline 6 & 67.66 & 1.67 & 20.60 & 35.00 & 26.37 & 8.63 & 6.7 & 36.70 & 74.76 \\
\hline 7 & 57.84 & 1.66 & 19.21 & 41.00 & 18.33 & 22.67 & 5.4 & 54.30 & 95.46 \\
\hline 8 & 45.50 & 1.68 & 15.76 & 33.00 & 20.00 & 13.00 & 5.9 & 21.00 & 50.75 \\
\hline 9 & 36.32 & 1.69 & 18.69 & 37.00 & 16.23 & 20.77 & 7.1 & 93.00 & 96.61 \\
\hline 10 & 45.06 & 1.70 & 18.40 & 45.00 & 24.05 & 20.95 & 5.2 & 68.00 & 91.08 \\
\hline
\end{tabular}

Table 2: Summary of the Laboratory Results

\begin{tabular}{cccccc}
\hline $\begin{array}{c}\text { Trial } \\
\text { pit No }\end{array}$ & \multicolumn{2}{c}{ Direct shear test } & $\begin{array}{c}\text { Moisture } \\
\text { Content }\end{array}$ & $\begin{array}{c}\text { Specific } \\
\text { Gravity test }\end{array}$ & Consolidation test \\
\hline & $\begin{array}{c}\text { Angle of Internal } \\
\text { Friction }\left(\varnothing^{\circ}\right)\end{array}$ & $\begin{array}{c}\text { Cohesive Strength } \\
\left(\mathrm{KN} / \mathrm{m}^{2}\right)\end{array}$ & $\begin{array}{c}\text { Average Moisture } \\
\text { Content }(\%)\end{array}$ & - & $\begin{array}{c}\text { Total Settlement Pc } \\
(\mathrm{M})\end{array}$ \\
$\mathbf{1}$ & 9 & 13 & 32.15 & 2.69 & 0.0013 \\
$\mathbf{2}$ & 6 & 15 & 17.30 & 2.57 & 0.0009 \\
$\mathbf{3}$ & 26 & 16 & 22.50 & 2.63 & 0.0019 \\
$\mathbf{4}$ & 17 & 23 & 37.15 & 2.64 & 0.0005 \\
$\mathbf{5}$ & 21 & 17 & 8.18 & 2.73 & 0.0008 \\
$\mathbf{6}$ & 15 & 13 & 31.77 & 2.63 & 0.0016 \\
$\mathbf{7}$ & 23 & 18 & 27.43 & 2.68 & 0.0019 \\
$\mathbf{8}$ & 24 & 22 & 41.16 & 2.71 & 0.0009 \\
$\mathbf{9}$ & 18 & 24 & 39.75 & 2.71 & 0.0008 \\
$\mathbf{1 0}$ & 14 & 16 & 46.36 & 2.73 & 0.0011 \\
\hline
\end{tabular}




\section{Discussion}

The result of the laboratory analyses are summarized in Table 1 and 2, while the revised AASHTO system of soil classification is contained in Table 3. The compaction classification of the soil is shown in table 4 and the geological map showing the rock lithologies are shown in Figure 4. Federal Ministry of Works and Housing general specification for roads and bridges is shown in Table 5 while the Casagrande Plasticity Chart of the soils is shown in Figure 5. From the results of the laboratory analysis (Table 1); The Atterberg limit test reveals that the; liquid limits value ranged from $33.0 \%$ to $45.0 \%$, plastic limits varied from $16.23 \%$ to $26.37 \%$, and the plasticity index is of the order $8.63 \%$ to $22.67 \%$. Atterberg limit is one of the most important geotechnical parameters in civil engineering works that helps to known the relative ease with which a soil can be deformed when interacts with water (Akintola et al., 2014). According to Nigerian Federal Ministry of Works and Housing (2010) for roads and bridges works the recommended liquid limits shall be less than but not greater than $35 \%$ and a maximum plasticity index shall be less than but not greater than $12 \%$ (table 5) for subgrade, sub-base and base materials; and this shows that only sample 1, 6 and 8 has falls within the specification. While for the Plasticity index only sample 6 has fall within the specification required. The values of the plastic limit are very important for the earth roads, clay core in an earth fill dam, foundation design, building, retaining walls, slab bridges, suitability of the soil on a slope and other excavation works. According to Prakash and Jain (2002) soil with Plasticity index greater than seventeen (PI>17) is clay and it will exhibit high plasticity with cohesive nature, and this can cause cracks, peeling, differential heave and deformation in engineering structures like buildings, roads, highway pavement and retaining walls when it absorbs water. According to Casagrande Plasticity Chart (figure 5), the soil can be classified as organic clay and silt.

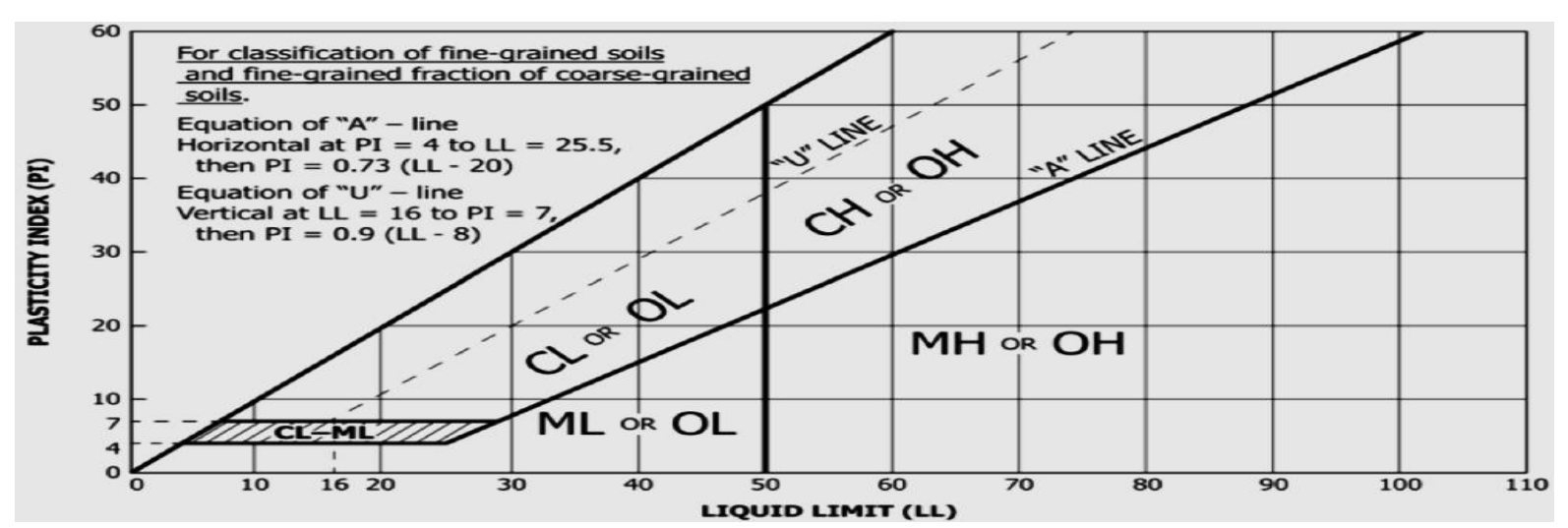

Figure 5: Casagrande Plasticity Chart (after Casagrande 1952).

The results of the sieve analysis of the soil also known as the grain size analysis reveals that the percentage passing ranges from $31.62 \%$ to $67.66 \%$ (Table 1). Apparao and Rao (1995) have explained that the grain size analysis is widely used in classification of soils. Bowles (2012) found that grain-size is one of the suitable criteria of soils for roads, airfield, levee, building, dam and other embankment construction. According to Nigerian Federal Ministry of Works and Housing (2010) (Table 5), the specification requirement for a sample to be used for civil engineering constructions like roads and bridges the percentage by weight of the soil passing the No. 200 sieves shall be less than but not greater than $35 \%$. Based on the AASHTO (2003) system of soil classification (Table 3), the samples under review were not good samples because the percentage by weight passing BS sieve No. 200 for the soil has exceed $35 \%$ except the sample collected at trial pit 5 (Table 1). The soil can be classified as silty-clay materials (A-4), (A-5), (A-6) and (A-7) based on the AASHTO (2003) system of soil classification. This shows that all these locations will be good for dam construction 
due to high percentage of clay and silt content in the soil which indicates low permeability (low hydraulic conductivity) and will not results to seepage problem.

Table 3: Revised AASHTO system of soil classification (2003).

\begin{tabular}{|c|c|c|c|c|c|c|c|c|c|c|}
\hline \multirow{3}{*}{$\begin{array}{l}\text { General } \\
\text { Classification } \\
\text { Group } \\
\text { Classification }\end{array}$} & \multicolumn{6}{|c|}{$\begin{array}{c}\text { General Materials } \\
(35 \% \text { or less passing } 0.075 \mathrm{~mm})\end{array}$} & \multicolumn{4}{|c|}{$\begin{array}{c}\text { Silt-clay materials } \\
\text { (more than } 35 \% \text { passing } 0.075 \mathrm{~mm} \text { ) }\end{array}$} \\
\hline & A-1 & A-3 & & & & & A-4 & A-5 & A-6 & A-7 \\
\hline & $\begin{array}{l}\text { A-1- A-1-b } \\
\text { a }\end{array}$ & & A-2-4 & A- $2-5$ & A-2-6 & A-2-7 & & & & $\begin{array}{l}\text { A-7-5 } \\
\text { A-7-6 }\end{array}$ \\
\hline $\begin{array}{l}\text { Sieve Analysis \% } \\
\text { passing } \\
2.00 \mathrm{~mm} \text { (No 10) } \\
0.425 \mathrm{~mm} \text { (No 40) } \\
0.725 \mathrm{~mm} \text { (No 200) }\end{array}$ & $\begin{array}{ll}50 \max & 50 \max \\
30 \max & 25 \max \\
15 \max & \end{array}$ & $\begin{array}{l}51 \min \\
10 \max \end{array}$ & $35 \max$ & $35 \max$ & $35 \max$ & $35 \max$ & $36 \mathrm{~min}$ & $36 \mathrm{~min}$ & $36 \mathrm{~min}$ & $36 \mathrm{~min}$ \\
\hline $\begin{array}{l}\text { Characteristics of } \\
\text { fraction passing } \\
\text { Liquid limit Plastic } \\
\text { Index }\end{array}$ & $6 \max$ & N.P & $\begin{array}{l}40 \max \\
10 \max \end{array}$ & $\begin{array}{l}41 \min \\
10 \max \end{array}$ & $\begin{array}{l}40 \max \\
11 \min \end{array}$ & $\begin{array}{l}41 \mathrm{~min} \\
11 \mathrm{~min}\end{array}$ & $\begin{array}{l}40 \max \\
10 \max \end{array}$ & $\begin{array}{l}41 \min \\
10 \max \end{array}$ & $\begin{array}{l}40 \max \\
11 \min \end{array}$ & $\begin{array}{l}40 \mathrm{~min} \\
11 \mathrm{~min}\end{array}$ \\
\hline $\begin{array}{l}\text { Usual types of } \\
\text { significant } \\
\text { constituent material } \\
\text { General rating }\end{array}$ & $\begin{array}{l}\text { Stone fragment } \\
\text { Gravel and sand }\end{array}$ & ine Sand & ellent to & r clayey & Iravel an & sand & Silty & oils & Clay & soils \\
\hline
\end{tabular}

From the results of the direct shear test (Table 2), the values of cohesive strength (c) ranges from $13 \mathrm{KN} / \mathrm{m}^{2}$ to $24 \mathrm{KN} / \mathrm{m}^{2}$ with angle of internal resistance $(\varnothing)$ that varied from $9^{\circ}$ to $26^{\circ}$. This shows that the soil is of silty-clay material due to high cohesive strength (c) and low angle of internal friction $(\varnothing)$. According to As per Mollahasani et al., (2011) soils with high plasticity like clayed soils exhibits higher cohesion and lower angle of internal resistance. This indicates that the soil will not be useful for the construction of civil engineering structures except earth dam. The result of the consolidation test shows that the total settlement $(\mathrm{Pc})$ ranges from $0.0005 \mathrm{~m}$ to $0.0019 \mathrm{~m}$ (Table 2). This may be attributed to the poor hydraulic conductivity of the soil; hence the soil will continue to reduce in volume over a long period of time after the immediate settlement and may be several times greater than the immediate settlement. According to Prakash and Jain (2002) consolidation data obtained from a soil is useful in predicting the rate and amount of settlement of civil engineering structures primarily due to volume change. The Soil $\mathrm{pH}$ values ranges from 5.2 to 7.8 (Table 1). Soil $\mathrm{pH}$ from $0-7$ is acidic, 7 are neutral and from 8-14 is alkaline Odesina (2012). The result of the soil $\mathrm{pH}$ shows that most of the soil samples are within the acidic limit except the sample collected at location 4 ,
5 and 9 which are neutral. According to Oyubu (2015) acidic soil can lead to extreme corrosion of metallic objects use in civil engineering constructions and this can results to structural damage. A neutral $\mathrm{pH}$ of 7 is most desirable to minimize the potential damage to earthen structures. Olayinkanola et al., (2016) reported that fine-grained soils such as clays and some silts are considered to have a greater corrosion potential because they typically have low hydraulic conductivity resulting from the accumulation of acid and base forming materials which cannot be leached out very quickly. Soil pH below and above 7 can have strong influence on the engineering properties of the soil in the presence of moisture/water. The specific gravity for the studied soil samples ranged from 2.57-2.73 (Table 2). According to specification, a good lateritic material should have specific gravity ranging from 2.50-2.75. Based on the samples under review it has fall within the acceptable specification. According to Roy and Dass (2014) increase in specific gravity can increase the shear strength parameters (cohesion and angle of shearing resistance). Based on the result, it shows that the soil can be recommended for the construction of civil engineering structures such as; roads, bridges, buildings, airfield and retaining walls. The specific gravity is an important index property 
of soils that is closely linked with mineralogy or chemical composition (Oyediran and Durojaiye, 2011). The results of the Natural moisture content test of the soil varied from $8.18 \%$ to $46.36 \%$ (Table 2). According to Ramamurthy and Sitharam (2005) moisture content is one of the factors that affect dry density of soils. The moisture content of various soils generally ranges from $10 \%$ to $15 \%$ for sand, $15 \%$ to $30 \%$ for silt and $30 \%$ to $50 \%$ for clay. Some soil such as bay mud has moisture contents of $100 \%$ to $200 \%$ (Sidi et al., 2015). The result shows that most of the soils within the study area are silty-clay material with the exception of location 5. These indicate poor water absorption capacity and can be problematic to civil engineering structures due to its expansive nature when comes in contact with water and cracks when shrink. The reason for high moisture content of the soil could be attributed to the fact that high rainfall could have increase the water table. The low value of natural moisture content indicates that the water table fluctuates during the dry season.
The results of the compaction test shows that; the Optimum Moisture Content (OMC) of the soil ranged from $15.22 \%-20.60 \%$ while that of maximum dry density (MDD) varied between $1.62 \mathrm{mg} / \mathrm{cm}^{3}-1.84 \mathrm{mg} / \mathrm{cm}^{3}$ (Table 1). According to $\mathrm{O}$ "Flaherty (2001) the ranges of values that may be anticipated when using the standard proctor test methods are: for clay, OMC may fall between 20\%-30\% and Maximum Dry Density (MDD) between $1.44 \mathrm{mg} / \mathrm{m}^{3}-1.685 \mathrm{mg} / \mathrm{m}^{3}$. For silty clay OMC may range between $15 \%-25 \%$ and MDD between $1.60 \mathrm{mg} / \mathrm{m}^{3}-1.845 \mathrm{mg} / \mathrm{m}^{3}$. For sandy clay, OMC may fall between $8 \%-15 \%$ and MDD from $1.75 \mathrm{mg} / \mathrm{m}^{3}-2.165 \mathrm{mg} / \mathrm{m}^{3}$ (Table 4). Looking at the results, it could be noticed that the samples are silty-clay. The results will help to evaluate the quality of compacted fills and the stability of earthen dams, embankments, roads, buildings, retaining walls and airfield. According to Kaniraj (1988), Apparao and Rao (1995) compaction increases the shear strength, reduces compressibility and permeability of the soil.

Table 4: Compaction Classification (Modified from O'Flaherty 2001).

\begin{tabular}{ccc}
\hline Maximum Dry Density $\left(\mathbf{M g} / \mathbf{m}^{\mathbf{3}}\right)$ & Optimum Moisture Content (\%) & Classification \\
\hline $1.44-1.685$ & $20-30$ & Clay \\
$1.60-1.845$ & $15-25$ & Silty-clay \\
$1.75-2.165$ & $8-15$ & Sandy-clay \\
\hline
\end{tabular}

The values of the California Bearing Ratio (CBR) test for the soaked and un-soaked soil samples range from $21.0 \%$ to $93.0 \%$ and $50.75 \%$ to $96.61 \%$ (Table 1). According to Nigerian Federal Ministry of Works and Housing (2010) the recommended values to be used for sub-grade, sub-base and base materials should be $\geq 10 \%, \geq 30 \%$ and $\geq 80 \%$ respectively (Table 5). The California Bearing Ratio (CBR) test for the Soaked soil samples shows that samples collected at location 1, 2, 4, 5, 6, 7, 9 and 10 has passed the recommended value for the sub-base with the exception of samples collected at location 3 and 8 which can only serve as an excellent sub- grade material. While the California Bearing Ratio (CBR) test for the un-soaked soil samples shows that samples collected at location 1, 2, 3, 4, 5, 6 and 8 has not passed the recommended value for the Base-course it can only serve as an excellent material for sub-base except the sample collected at location 7,9 and 10. The overall rating of the soil samples shows that most of the soil can mostly be used as subbase materials. The values of the California Bearing Ratio (CBR) test can be used to evaluate the potential strength of sub-grade, sub-base and base course materials for supporting road, railway, airfield, bridge, building and design of flexible pavements. 
Assessment of Geotechnical Parameters of Lateritic Soil of Jos and Environs, for Civil Engineering ...

Table 5: Nigerian specification of soil for the constructions of roads and bridges (2010).

\begin{tabular}{|c|c|c|c|c|c|c|c|c|c|c|}
\hline Location & 1 & 2 & 3 & 4 & 5 & 6 & 7 & 8 & 9 & 10 \\
\hline Sample & $\mathrm{P} 1$ & $\mathrm{P} 2$ & P3 & $\mathrm{P} 4$ & P5 & P6 & P7 & P8 & P9 & P10 \\
\hline \multirow[t]{2}{*}{ L.L $(\leq 35 \%)$} & 34.00 & 43.00 & 39.00 & 38.00 & 42.00 & 35.00 & 41.00 & 33.00 & 37.00 & 45.00 \\
\hline & Pass & Fail & Fail & Fail & Fail & Pass & Fail & Pass & Fail & Fail \\
\hline P.I $(\leq 12 \%)$ & 14.86 & 20.85 & 13.34 & 19.67 & 17.95 & 8.63 & 22.67 & 13.00 & 20.77 & 20.95 \\
\hline Comment & Fail & Fail & Fail & Fail & Fail & Pass & Fail & Fail & Fail & Fail \\
\hline C.B.R soaked & 31.00 & 49.50 & 26.30 & 74.70 & 82.70 & 36.70 & 54.30 & 21.00 & 93.00 & 68.00 \\
\hline $\begin{array}{l}\text { for Sub-base } \\
(\geq 30 \%)\end{array}$ & Pass & Pass & Fail & Pass & Pass & Pass & Pass & Fail & Pass & Pass \\
\hline C.B.R un-soaked & 79.47 & 74.50 & 75.10 & 68.31 & 71.85 & 74.76 & 95.46 & 50.88 & 96.51 & 91.08 \\
\hline $\begin{array}{l}\text { Base-course } \\
(\geq 80 \%)\end{array}$ & Fail & Fail & Fail & Fail & Fail & Fail & Pass & Fail & Pass & Pass \\
\hline Overall Rating & $\begin{array}{l}\text { Sub } \\
\text { base }\end{array}$ & $\begin{array}{l}\text { Sub } \\
\text { base }\end{array}$ & $\begin{array}{l}\text { Sub } \\
\text { base }\end{array}$ & $\begin{array}{l}\text { Sub } \\
\text { base }\end{array}$ & $\begin{array}{l}\text { Sub } \\
\text { base }\end{array}$ & $\begin{array}{l}\text { Sub } \\
\text { base }\end{array}$ & $\begin{array}{l}\text { Base } \\
\text { course }\end{array}$ & $\begin{array}{l}\text { Sub } \\
\text { base }\end{array}$ & $\begin{array}{l}\text { Base } \\
\text { course }\end{array}$ & $\begin{array}{l}\text { Base } \\
\text { course }\end{array}$ \\
\hline
\end{tabular}

\section{Conclusion}

The geotechnical assessment of the lateritic soil of Jos and Environs, North Central part of Nigeria was carried out in accordance with British Standard (BS) methods of soil testing (BS 13771990 and BSI 5930 1990) for civil engineers. The geotechnical parameters obtained shows that the soil samples are silty-clayey materials which are unsuitable for most civil engineering constructions because they have poor bearing capacities. They would make fair to poor subgrades because of their grain sizes and relatively high plasticity index but can be useful as dam embankment materials. Hence great care must be taken when they are put to use in civil engineering work. This is because silty-clays materials can be expansive in nature especially when they come in contact with water and can exhibit cracks when it shrinks. Conclusively, the possible causes of cracks, potholes, peeling and deformations seen on the roads and buildings could be as a result of siltyclay materials and this can reduce its life span leading to structural damage because of the use of material with low bearing capacity.

\section{References}

AASHTO M145-91 (2003). Standard specifications for Classification of soils and soil-Aggregates Mixtures for Highway construction purposes.

Abiem, I., (2016). Vegetation Patterns and Species diversity of Naraguta Mountains in Jos, North-Central Nigeria, the Ruffor Foundation.
Abubakar, J. B., (2016). "Geotechnical study of lateritic soil in Tipper garage, Katampe Area, Abuja, Federal capital territory". Academic Research Sciences, Technology \& Engineering, 2(7), 4-34.

Agbede, O. A., (1992). "Characteristic of Tropical Red Soils as Foundation Materials". Nigeria. J. of Science. 26, 237242.

Akanbi, E. S., \& Makama, E. K., (2010). Application of Least Squares Method (LSM) in the Separation of Aeroradiometric Anomalies of Naraguta area, Sheet 168, North Central Nigeria. Nigerian Journal of Physics, 1(18), 53-62

Akanbi, E. S., Ugodulunwa, F. X. O., \& Gyang, B.N., (2012). Mapping Potential Cassiterite Deposits of Naraguta Area, North Central, Nigeria Using Geophysics and Geographic Information System (GIS). Journal of Natural Sciences Research, 2(8),132-143.

Akintola, O.O., Bodede, I.A., \& Ariyo, S.O., (2014). Geotechnical evaluation of a location as landfill site near Ilupeju SouthWestern Nigeria. Proceedings of fourth international Conference of Nigeria Association of Engineering Geology and the Environment (NAEGE), October 2019, Abuja, Nigeria.

Anderson, N., \& Croxton, N., (2008). Introduction to Geotechnical Geophysics, In: Transport Research Circular Number E-C130: Geophysical methods commonly employed for Geotechnical Site Characterization, Transport Research Board of the National Academies, 2-12. 
Alkali, S. C., \& Yusuf, S. N., (2010). Gravity Study over Jos-Bukuru Younger Granite Complex, North Central Nigeria. Archives of Physics Research, 1(4), 178-191.

Amadi, A. N., Eze, C. J., Igwe, C. O., Okunlola, I. A., \& Okoye, N.O., (2012). Architects and Geologist's view on the causes of building failures in Nigeria. Modern Applied Science, 6 (6), 31-38.

Arora, K. R. (2008).Soil Mechanics and Foundation Engineering (Geotechnical Engineering), Standard Publishers Distributors, Delhi.

Apparao, K.V.S., \& Rao, V.C.S., (1995). Soil Testing Laboratory Manual and Question Bank, Universal Science Press, New Delhi.

Atterberg, A., (1911). On the investigation of the physical properties of soil and on the Plasticity of clays, Int. Mitt. Fur Bodenkunde, 1, 10-43.

Behzad, K., \& Huat, B. B. K., (2008). Peat Soil Stabilization using Ordinary Portland Cement, Polypropylene Fibers, and Air Curing Technique, EJGE, USA, 13,1 .

Billong, N., Melo, U. C., Louvet, F., \& Njopwouo, D., (2009). Properties of compressed Lateritic soil stabilized with a burnt clay lime binder: Effect of mixture Components. Build. Mater. 23, 2357- 2360.

Bowles, J. E., (2012). Engineering Properties of Soils and their Measurement, 4th edition, McGraw Hill Education (India) Private Limited, New Delhi.

British Standard (BS) 1377 (1990). Methods of testing soils for civil engineering purposes. British Standards Institutions, London.

British Standard Institute (BSI) 1377 (1990). Code of practice for site investigation. London, 148.

Caleb, A. T., Adeyinka, O., Miranda, N. M., \& Abdulmalik, S., (2013). Structurally Failed Dam: A Case Study of Cham Dam, North-Eastern Nigeria. Journal of Environment and Earth Science, 3, 7.

Casagrande, A.,(1952).Classification and identification of soils, transactions of the
American Society of civil engineering, $113,901$.

Daku, S. S., Diyelmak, V. B., Otitolaiye, O. A., \& Abalaka, I. E., (2019). Evaluation of soil Corrosivity using Electrical Resistivity Method: A case study of part of the University of Jos Permanent Site. Scientific Research Journal (SCIRJ), 7(3), 22012796.

Gidigasu, M.D., (1976). Laterite Soil Engineering: Pedogenesis and Engineering Principles. Elsevier Scientific Publication Company. Amsterdam.

Hamard, E., Cazacliu, B., Razakamanantsoa, A., \& Morel, J. C., (2016). Cob, a vernacular earth construction process in the context of modern sustainable building. Building and Environment, 106, 103-119.

Kaniraj, S. R., (1988). Design Aids in Soil Mechanics and Foundation Engineering, McGraw Hill Education (India) Private Limited, New Delhi.

Lar, U.A., Wazoh, H.N., Mallo S. J., \& Chup, A. S., (2011). Geotechnical Characterization of Lateritic Soils in Jos and Environs, North Central Nigeria. Nigerian Mining Journal, 9(1), 9-19.

Laskar, A., \& Pal, S. K., (2012). Geotechnical characteristics of two different soils and their mixture and relationships between parameters, EJGE, 17, 2821-2832.

Mollahasani, A., Alavi, A.H., Gandomi, A. H., $\&$ Rashed, A., (2011). Nonlinear neuralbased modeling of soil cohesion intercept. KSCE J CIV ENG., 15(5), 831840.

Ngah, S. A., \& Nwankwoala, H. O., (2013). Evaluation of geotechnical properties of the sub-soil for shallow foundation design in Onne, Rivers State, Nigeria., The IJES., 2 (11), 08-16.

Nigerian Federal Ministry of Works and Housing (2010). General Specification for Roads and Bridges, Volume II, Federal Highway Department, FMWH: Lagos, Nigeria, 317.

Nwankwoala, H. O., \& Amadi, A. N., (2013). Geotechnical Investigation of Sub-soil and Rock Characteristics in parts of Shiroro - Muya Chanchaga Area of Niger 
State, Nigeria. International Journal of Earth Sciences and Engineering, 6(1), 817.

Nwankwoala, H.O., \& Warmate, T., (2014). Geotechnical assessment of foundation conditions of a site in Ubima, Ikwerre Local Government Area, Rivers State, Nigeria, IJERD, 9(8), 50-63.

Nwankwoala, H.O., Amadi, A. N., Ushie, F. A., \&Warmate, T., (2014). Determination of Subsurface Geotechnical properties for Foundation Design and Construction in Akenfa Community, Bayelsa State, Nigeria. American Journal of Civil Engineering and Architecture, 2(4), 130135.

Odesina, I. A., (2012). Essential Chemistry for Senior Secondary Schools $3^{\text {rd }}$ edition, Tonad Publishers.

O'Flaherty, C. A., (2001). Soils for Road work: In: O'Flaherty, C. A. (ed). Highways the location, Design, Construction and maintenance of pavements. 133. www.amazon.com.

Oghenero, A. E., Akpokodje, E. G., \& Tse, A. C., (2014). Geotechnical properties of subsurface soils in Warri, Western Niger Delta, Nigeria. Journal of Earth Sciences and Geotechnical Engineering., 4(1), 89-102.

Oke, S. A., \& Amadi, A.N., (2008). An assessment of the geotechnical properties of the sub-soil of parts of Federal University of Technology, Minna, Gidan Kwano Campus, for foundation design and construction, $J$ Sci Educ Technol.,1(2), 87-102.

Oke, S. A., Okeke, O. E., Amadi, A.N., \& Onoduku, U. S., (2009b). Geotechnical Properties of the Subsoil for Designing Shallow Foundation in some selected parts of Chanchaga area, Minna, Nigeria. Journal of Environmental Science, 1(1),45-54.

Oke, S. A., Amadi, A.N., Abalaka, A. E., Nwosu, J. E., \& Ajibade, S. A., (2009a). Index and Compaction Properties of Laterite Deposit for Road Construction in Minna Area, Nigeria. Nigerian Journal of Construction Technology and Management, 10 (1\&2), 28-35.
Olasehinde, A., Ashano, E. C., \& Singh, G. P., (2012). Structural analysis the Ropp Complex, North Central Nigeria, using magnetic anomaly and Landsat ETM imagery. Continental J. Earth Sciences, 7 (1), 1-8.

Olayinkanola, L. O. A., Fajemiroye, J. A., Tijani, B. O., \& Oke, D. A., (2016). Correlation between Soil Electrical Resistivity and Metal Corrosion based on Soil Types for Structural Designs. Scientific Research Journal (SCIRJ), 4, 2201-2796.

Omotoso, O. A., (2010). An Investigation into the geotechnical and engineering Properties of some laterites of Eastern Nigeria. Journal of Nigeria Mining Geology and Metallurgical Society, 1, 10-110.

Oyediran, A., \& Durojaiye, H. F., (2011). Variability in the geotechnical properties of some residual clay soils from south western Nigeria. IJSER. 2(9), 1-6.

Oyubu, A. O., (2015). Soil Resistivity and Soil $\mathrm{pH}$ profile Investigation: A case study of Delta State University Faculty of Engineering Complex. International Journal of Scientific \& Engineering Research, 6(10), 2229-5518.

Prakash, S., \& Jain, P. K., (2002). Engineering Soil Testing, Nem Chand \& Bros, Roorkee. Ramamurthy, T. N., \& Sitharam, T. G., (2005). "Geotechnical engineering" $S$. Chand and Company Limited, Ram Nagar, New Delhi.

Raj, P. P., (2012). Soil Mechanics and Foundation Engineering, Dorling Kindersley (India) Pvt. Ltd., New Delhi.

Roy, S., \& Dass, G., (2014).Statistical models for the prediction of shear strength parameters at Sirsa, India., I. Journal of Civil and Structural Engineering., 4(4), 483-498.

Roy, S., \& Bhalla, S. K., (2017). Role of geotechnical properties of Soil on Civil engineering Structures. Resources and Environment, 7(4), 103-109.

Salami, B.M., (2017). Geotechnical and Geoelectrical Characterization of Subgrade Soils for Pavement failure Assessment along Ilaro-Shagamu 
Highway, Southwestern Nigeria. Unpub. $\mathrm{Ph}$. D. Thesis, Obafemi Awolowo University, Ile-Ife, 310.

Sidi, M. W., Thaffa, A. B., \& Garga, A., (2015). Geotechnical Investigation of Soil around Arawa-Kundulum Area of Gombe Town, North-Eastern Nigeria, Nigeria. Journal of Applied Geology and Geophysics, 3(1), 7-15.

Simon, A. B., Giesecke, J., \& Bidlo, G., (1973). Use of lateritic soil for road construction in North Dahomey. Engineering Geology, 7, 197-218.

Smith, G.N., \& Smith, I.G.N., (1998). Elements of Soil Mechanics, 7th Edition, Blackwell Science, Inc., USA.
Tharaka, D.G.S., \& Mampearachchi, W.K., (2012). Suitability of cohesion less soil as a Highway construction material. Civil engineering research exchange symposium, Faculty of Engineering University of Ruhuna, Sri Lanka.

Williams, J. H., (2016). Engineering GeologyDefinitions and Historical Development Applications in Life Support Systems, 32.

Youdeowei, P.O., \& Nwankwoala, H.O., (2013). Suitability of soils as bearing media at a freshwater swamp terrain in the Niger Delta. J. Geol. Min. Res., 5(3), 58-64. 